\title{
Association analysis of polymorphisms of $G$ protein-coupled receptor 54 gene exons with reproductive traits in Jiaxing Black sows
}

\author{
Fen Wu ${ }^{1, a}$, Wei Zhang ${ }^{1, a}$, Qian-Qian Song ${ }^{1}$, Hai-Hong Li' ${ }^{2}$, Ming-Shu $\mathrm{Xu}^{2}$, Guo-Liang Liư ${ }^{2}$ and Jin-Zhi Zhang ${ }^{1, *}$
}

* Corresponding Author: Jin-Zhi Zhang Tel: +86-0571-88982308, Fax: +86-0571-88982308, E-mail: zhangjzs@zju.edu.cn

'College of Animal Sciences, Zhejiang University, Hangzhou 310058, China

${ }^{2}$ Zhejiang Qinglian Food Company Limited, Jiaxing 314000, China

a These authors contributed equally to this work.

\section{ORCID}

Fen Wu

https://orcid.org/0000-0002-0563-5887

Wei Zhang

https://orcid.org/0000-0002-2651-3790

Qian-Qian Song

https://orcid.org/0000-0002-7252-3148

Hai-Hong Li

https://orcid.org/0000-0002-0794-2581

Ming-Shu Xu

https://orcid.org/0000-0002-3684-6695

Guo-Liang Liu

https://orcid.org/0000-0002-8084-2210

Jin-Zhi Zhang

https://orcid.org/0000-0002-8450-2352

Submitted Nov 6, 2018; Revised Dec 5, 2018; Accepted Dec 18, 2018
Objective: The aim of this study was to detect single nucleotide polymorphisms (SNP) of G protein-coupled receptor 54 (GPR54) gene and explore association of this candidate gene with reproductive traits in Jiaxing Black sows.

Methods: Six pairs of primers of the gene were designed to amplify all exons thus sequences of which were detected by means of direct sequencing and then SNP loci were scanned. The effects of SNPs on total number of piglets born (TNB), number of piglets born alive (NBA), number of still born piglets (NSB), and litter weight at birth (LWB) of Jiaxing Black sows were analyzed.

Results: Three SNP loci, including T3739C, C3878T and T6789C, were identified via comparison of sequencing and two genotypes $(\mathrm{AB}, \mathrm{BB})$ at each $\mathrm{SNP}$ site were observed. T3739C resulted in the change of amino acid (Leu $\rightarrow$ Pro) in corresponding protein, and C3878T resulted in synonymous mutation (Ile $\rightarrow$ Ile). Statistical results demonstrated that allele B was the preponderant allele at the three SNP loci and Genotype BB was the preponderant genotype. Meanwhile, Chi-Square test of these three SNPs indicated that all mutation sites fitted in Hardy-Weinberg equilibrium ( $\mathrm{p}>0.05)$. For GPR54-T3739C locus, Jiaxing Black sows with genotype $\mathrm{BB}$ had $1.23 \mathrm{TNB}$ and $1.28 \mathrm{NBA}(\mathrm{p}<0.01)$ that were more than those with genotype $A B$, respectively. Jiaxing Black sows that had the first two parities with genotype $B B$ had additional 2.23 TNB, 2.27 NBA $(\mathrm{p}<0.01)$, and 1.94 LWB $(\mathrm{p}<0.05)$ compared to those with genotype $A B$, respectively. However, for other two loci, no significant difference was found between TNB, NBA, NSB, and LWB, and different genotypes of Jiaxing Black sows.

Conclusion: In conclusion, the polymorphisms of GPR54-T3739C locus were significantly associated to TNB, NBA, and LWB and could be used as a potential genetic marker to improve reproductive function of Jiaxing black sows.

Keywords: Jiaxing Black Sows; G Protein-coupled Receptor 54 (GPR54); Single Nucleotide Polymorphisms; Reproductive Traits

\section{INTRODUCTION}

G protein-coupled receptor 54 (GPR54) gene, initially cloned from rat brain in 1999, is also referred to as kisspeptin 1 receptor (KiSS-1R) or AXOR12 gene [1]. GPR54, also known as a member of the rhodopsin family of $G$ protein-coupled receptors, is the endogenous receptor of kisspetins which are peptides derived from KiSS-1 gene [2-4]. The human GPR54 gene is mapped to chromosome 19p13.3 and consists of five exons interrupted by four introns with an open reading frame (ORF) of 1,197 bp encoding a protein of 398 amino acids $[1,5]$. The pig GPR54 gene (GenBankTM accession number NC_010444.4) is mapped to chromosome 2q21-24 and has six exons and five introns.

KiSS-1/GPR54 system is generally considered as the essential regulator of puberty onset 
and reproductive function in many species [6]. So far, there have been many studies that reported that KiSS-1 gene could function as candidate gene for reproductive traits in animals, which revealed that this gene played an important role in animal reproduction [7-9]. Kisspeptins, encoded by KiSS-1 gene, are the endogenous ligands for the GPR54 and are able to directly stimulate gonadotropin-releasing hormone release (GnRH) via GPR54 [10,11]. Central and peripheral administration of kisspeptins could stimulate GnRH-dependent luteinizing hormone (LH) and follicle-stimulating hormone (FSH) release, and activate the development of puberty and gonadotropic axis $[6,12,13]$. Thus, it's meaningful to hypothesize that GPR54 could make a difference in complicated molecular mechanism of animal prolificacy.

GPR54 gene ubiquitously expressed, with high mRNA levels in placenta [14], pituitary, pancreas [4], and limbic brain regions including the hypothalamus, hippocampus, and periaqueductal gray etc $[1,15]$. More recent studies regarding GPR54 mRNA in situ hybridization have concentrated solely on identifying its presence in GnRH neurons [16,17]. Herbison et al using dual-labeling experiments showed that essentially all GPR54expressing cells in the rostral preoptic area of nervous system were GnRH neurons as well [15]. Navarro et al [6] found that hypothalamic expression of GPR54 gene changed throughout the estrous cycle, and anoestrus sows had lower hypothalamic GPR54 mRNA content than estrus cyclic sows significantly [18].

Numerous studies have identified that inactivating mutations in GPR54 gene could result in idiopathic hypogonadotropic hypogonadism (IHH) with delaying puberty onset and influencing FSH or LH secretion in human [19-22], which resembled the phenomenon observed in GPR54-deficient mice $[14,19]$. Meanwhile, other reports showed that activating mutations in GPR54 could give rise to central precocious puberty (CPP) in human with premature activation of $\mathrm{GnRH}$ releasing $[23,24]$.

Up to now, there have been some research findings that have identified the GPR54 gene is associated with puberty and reproductive performance in animals, such as human [19-21], sheep [18,25], monkey [11], mice [14,19], and forth on. According to the studies above, its possible to hypothesize that the polymorphisms of GPR54 gene are related to sows' reproductive function. However, the literatures concerning GPR54 gene and sows' prolificacy were limited. Jiaxing Black pig, a famous local breed in China, is known for its significant characteristics of high prolificacy, sexual precocity, high adaptation and roughage-resistance and so on. In the present study, Jiaxing Black sows were selected as test animals, then we explored single nucleotide polymorphisms (SNPs) in GPR54 gene by sequencing and further analyzed its hereditary effects on reproductive traits including total number of piglets born (TNB), number of piglets born alive (NBA), number of still born piglets (NSB), and litter weight at birth (LWB) in three different parities population. The aim of this study was to offer efficient molecular genetic markers for improving sow prolificacy and breeding.

\section{MATERIALS AND METHODS}

All procedures involving animals were conducted in accordance with Chinese guidelines for animal welfare and approved by the animal welfare committee of the Animal Science College, Zhejiang University.

\section{Sample collection and DNA extraction}

A total of 128 Jiaxing Black sows (Zhejiang Qinglian Food Company Limited located in Jiaxing City, Zhejiang Province, PR China) were selected randomly as test objects, in which there are 47 primiparous sows (the first two parities) and 81 multiparous sows (later parities), and collected their ear tissue samples, along with the data on TNB, NBA, NSB, and LWB from each sow. Took $150 \mathrm{mg}$ ear tissue and cut into pieces in an Eppendorf tube to extract DNA according to the instructions of the Tiangen Genoic DNA Extraction Kit. DNA concentration and optical density value were determined with the equipment Nano 2000, and then DNA concentration was tested by electrophoresis on $1 \%$ agarose gels. At last, the extracted DNA were stored at $-20^{\circ} \mathrm{C}$ for subsequent experiments.

\section{Primer design and polymerase chain reaction amplification}

According to the reference sequence of GPR54 gene provided by GenBank, six pairs of primers were designed and utilized for amplification of exon1, exon2, exon3, exon4, exon5, and exon6 of this gene (Table 1). These primers were all designed by Primer 5.0 and synthesized by Hangzhou Tsingke Biotechnology Company Limited (Hangzhou, Zhejiang, China). Polymerase chain reaction (PCR) was performed in a $25 \mu \mathrm{L}$ reaction volume which was composed of $2 \times$ Taq Master Mix $12.5 \mu \mathrm{L}$, forward primer $1 \mu \mathrm{L}$, reversed primer $1 \mu \mathrm{L}$, DNA template $2 \mu \mathrm{L}, \mathrm{ddH}_{2} \mathrm{O} 8.5 \mu \mathrm{L}$. PCR amplification conditions are listed as followed: pre-denaturation at $94^{\circ} \mathrm{C}$ for $5 \mathrm{~min}$, followed by 30 cycles of denaturation at $94^{\circ} \mathrm{C}$ for $30 \mathrm{~s}$, annealing at $55^{\circ} \mathrm{C}$ for $30 \mathrm{~s}$, extension at $72^{\circ} \mathrm{C}$ for $1 \mathrm{~min}$, finally extension at $72^{\circ} \mathrm{C}$ for $4 \mathrm{~min}$. The PCR products were separated by electrophoresis on $1 \%$ agarose gels in parallel with a 2,000 bp DNA marker, then purified and recycled, ultimately sequenced by Hangzhou Tsingke Biotechnology Company Limited (China).

\section{Polymorphism scanning and genotyping}

Reference sequence was selected from Genbank program on NCBI (https://www.ncbi.nlm.nih.gov/). Sequence data were edited by Chromas Application Ver.1.0.0.1. Multiple sequences alignments were performed with SeqMan program of DNA- 
Table 1. Primer sequencing for GPR54 gene exons

\begin{tabular}{lcll}
\hline Gene & Amplification region & \multicolumn{1}{c}{ Forward primer $\left(\mathbf{5}^{\prime} \rightarrow \mathbf{3}^{\prime}\right)$} & \multicolumn{1}{c}{ Reversed primer $\left(\mathbf{5}^{\prime} \boldsymbol{\rightarrow} \mathbf{3}^{\prime}\right)$} \\
\hline GPR54 & Exon1 & AACGCTACCATAGCTCGGACA & TGGAAGGAAGCCCTGTTTGT \\
GPR54 & Exon2 & GGAAGAGTGCCACACGGTGATG & AGCTCTCCATGTGCCACACTCTC \\
GPR54 & Exon3 & ACTTCTCTGCACAAGGATGTCAGC & GCCTCCTGTCAGTCACTCTGTCCA \\
GPR54 & Exon4 & CCTGGGCTTCTCTTCTCCTATCC & CTTAAGCGCGTCCGAGGAGC \\
GPR54 & Exon5 & CATCCGGGAATGGGCTCAAT & GGGCGACACACCAGGCACTT \\
GPR54 & Exon6 & GGGAAGTGCCTGGTGTGTG & GGCAGTGTGGGAAACTTCTATTGAT \\
\hline
\end{tabular}

GPR54, G protein-coupled receptor 54 .

STAR software to identify SNPs. The coding DNA sequences of different exonic regions were conceptually translated to amino acid sequences using DNAMAN software (Lynnon Biosoft, San Ramon, CA, USA).

\section{Statistics analysis}

Genotype frequency, gene frequency, polymorphism information content (PIC), population heterozygosity, and effective allele number at each SNP locus in GPR54 gene were calculated using Excel, then $\chi^{2}$ Hardy-Weinberg balance test was performed. The general lineal model of SPSS 19.0 was employed for analysis of the effects of different parities and genotypes on reproductive traits (TNB, NBA, NSB, and LWB) of Jiaxing Black sows. The statistical model was $Y_{\mathrm{ijk}}=\mu+\mathrm{P}_{\mathrm{i}}+\mathrm{G}_{\mathrm{j}}$ $+\mathrm{e}_{\mathrm{ijk}}$. Where $Y_{\mathrm{ijk}}$ is individual observation for traits, $\mu$ is overall population mean, $P_{i}$ is effect of parity, $G_{j}$ is effect of gene, $\mathrm{e}_{\mathrm{ijk}}$ is random residual effect. Student' T-test was used to compare differences among means.

\section{RESULTS}

Polymerase chain reaction amplification of GPR54 gene exons

All six exons of GPR54 gene were successfully amplified using Jiaxing Black sows' genetic DNA and six pairs of primers. GPR54-Exon2 and GPR54-Exon6 were selected as examples, the PCR products were detected by electrophoresis on $1 \%$ agarose gels in parallel with a 2,000 bp DNA marker. The amplified fragments sizes were approximately consistent with the target ones which were $800 \mathrm{bp}$ and $786 \mathrm{bp}$ in length (Figure 1), respectively, and had a good specificity so that the PCR products could be purified and recycled according to the instructions of the Gel Extraction Kit (Tsingke Biotechnology Co., Ltd, China). Splicing of exons and introns were consistent with the GT-AG rule.

\section{Single nucleotide polymorphisms identification and genotyping}

Comparison of amplified sequences of Jiaxing Black sows resulted in identification of three SNPs in GPR54 gene exons (Figure 2), in which two (T3739C and C3878T) were located within GPR54-Exon2 region and one (T6789C) within GPR54Exon6 region. But no SNPs were found in other exonic regions of GPR54 gene. Three SNP loci all expressed two possible genotypes $(\mathrm{AB}, \mathrm{BB})$ without genotype $\mathrm{AA}$, this may reflect the small sample size. T3739C and C3878T situated in the first ORF of GPR54 gene, the former resulted in the change of amino acid (Leu $\rightarrow$ Pro) in corresponding protein and the latter resulted in synonymous mutation (Ile $\rightarrow$ Ile). T6789C situated in untranslated regions. Thus, T3739C could be considered as a locus that might have associations with the functional traits.

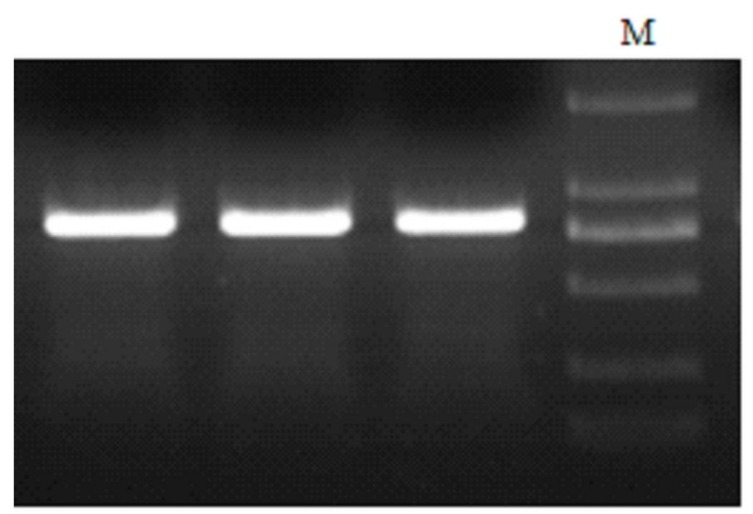

GPR54-Exon2

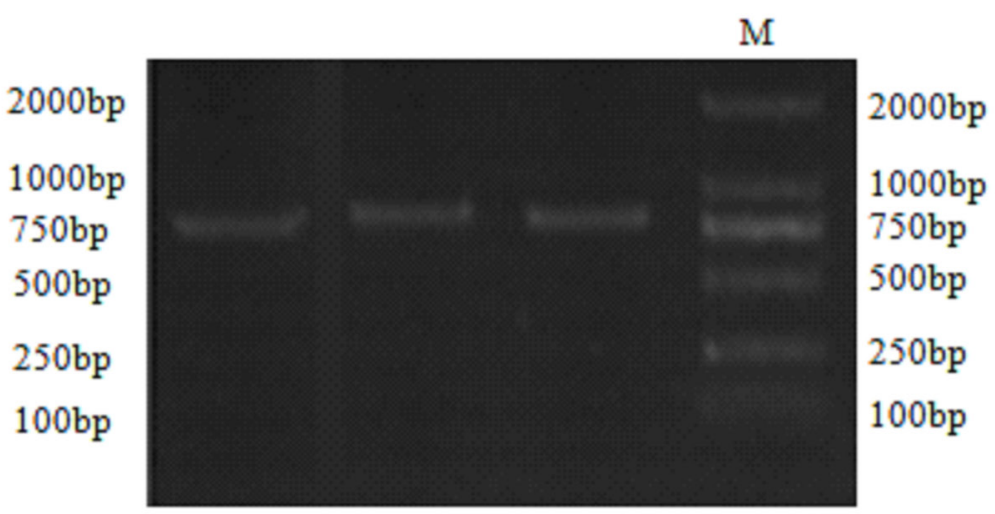

GPR54-Exon6

Figure 1. Results of GPR54-Exon2 and GPR54-Exon6 amplification. M: DL 2000 DNA marker. GPR54, G protein-coupled receptor 54. 


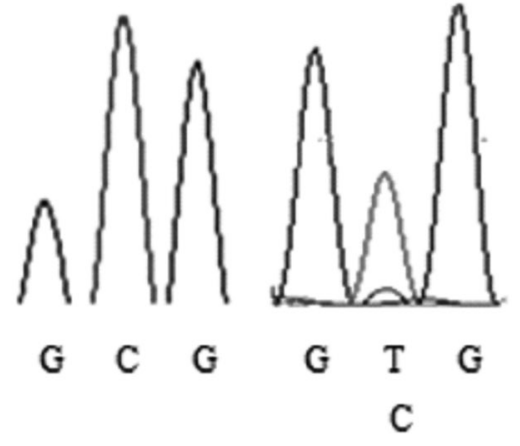

BB

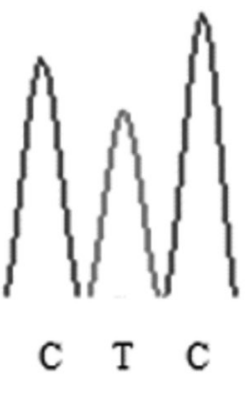

BB

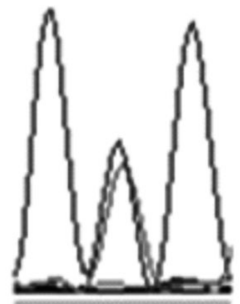

C C C $\mathrm{T}$

$A B$

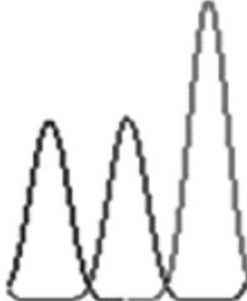

G C T

BB

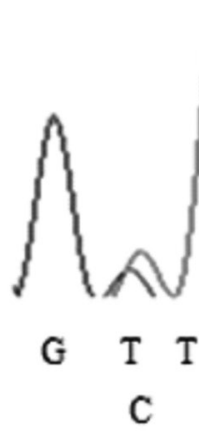

$\mathrm{AB}$

GPR54-T3739C

GPR54-C3878T

Figure 2. Results of polymerase chain reaction products sequencing.

Allele and genotype frequencies of different SNP loci in GPR54 gene in Jiaxing Black sows are presented in Table 2. Allele B was the preponderant allele in all the three SNPs in GPR54 gene and the frequencies were 0.94, 0.98, and 0.98, respectively. Genotype $\mathrm{BB}$ was the preponderant genotype and the frequencies were $0.88,0.95$, and 0.95 , respectively. The results of Chi-square test indicated that three SNPs loci fitted in Hardy-Weinberg equilibrium ( $p>0.05)$. According to the classification of PIC, low polymorphism if PIC value $<0.25$, moderate polymorphism if $0.25<\mathrm{PIC}$ value $<0.5$, and high polymorphism if PIC value $>0.50$, all SNP loci in GPR54 gene were in low polymorphism in this study.

Association analysis of single nucleotide polymorphisms with reproductive function

TNB, NBA, NSB, and LWB of Jiaxing Black sows in different parities are listed in Table 3. The TNB, NBA, NSB, and LWB in sows' population were $12.94,12.29,1.44$, and 13.89 , respectively. According to the comparison analysis between the first two parities and later parities, sows of the later parities had $0.96 \mathrm{TNB}, 1.03 \mathrm{NBA}$, and $0.88 \mathrm{NSB}$ more than those of sows of the first two parities respectively $(\mathrm{p}<0.01)$. It represented that there was a certain difference in reproductive performance in sows of different parities.

For GPR54-T3739C locus (Table 4), TNB, NBA, and LWB of sows with two genotypes in the three groups all showed $\mathrm{BB}>$ $A B$, but NSB showed $A B>B B$. Analysis results identified that sows of the total parities with genotype $\mathrm{BB}$ had $1.23 \mathrm{TNB}(\mathrm{p}<$ $0.01)$ and 1.28 NBA $(\mathrm{p}<0.01)$ more than those with genotype $A B$, respectively. Sows of the first two parities with genotype $\mathrm{BB}$ had 2.23 TNB ( $<<0.01), 2.27 \mathrm{NBA}(\mathrm{p}<0.01)$, and 1.94 LWB $(p<0.05)$ more than those with genotype $A B$, respectively. But

Table 2. Genotype distribution and allele frequencies of three SNPs in GPR54 gene

\begin{tabular}{|c|c|c|c|c|c|c|c|c|c|c|c|}
\hline \multirow{2}{*}{ Gene } & \multirow{2}{*}{ SNPS } & \multicolumn{3}{|c|}{ Genotype frequency } & \multicolumn{2}{|c|}{ Allele frequency } & \multirow{2}{*}{$\chi^{2}$} & \multirow{2}{*}{$p$-value } & \multirow{2}{*}{ PIC } & \multirow{2}{*}{$\mathrm{He}$} & \multirow{2}{*}{$\mathrm{Ne}$} \\
\hline & & $A A$ & $A B$ & BB & A & B & & & & & \\
\hline \multirow[t]{3}{*}{ GPR54 } & T3739C & - & 0.12 & 0.88 & 0.06 & 0.94 & 0.50 & 0.48 & 0.01 & 0.11 & 1.12 \\
\hline & C3878T & - & 0.05 & 0.95 & 0.03 & 0.97 & 0.10 & 0.75 & 0.05 & 0.05 & 1.06 \\
\hline & T6789C & - & 0.05 & 0.95 & 0.02 & 0.98 & 0.07 & 0.79 & 0.04 & 0.05 & 1.05 \\
\hline
\end{tabular}

SNPs, single nucleotide polymorphisms; GPR54, G protein-coupled receptor 54; PIC, polymorphism information content; He, heterozygosity; Ne, effective number of alleles.

Table 3. Reproductive function of Jiaxing Black sows

\begin{tabular}{|c|c|c|c|c|c|c|c|c|c|}
\hline \multirow{2}{*}{ Trait } & \multicolumn{3}{|c|}{ Total parities } & \multicolumn{3}{|c|}{ First two parities } & \multicolumn{3}{|c|}{ Later parities } \\
\hline & Mean \pm SE & Max & Min & Mean \pm SE & Max & Min & Mean \pm SE & Max & Min \\
\hline TNB & $12.94 \pm 0.14$ & 16.50 & 6.00 & $12.33 \pm 0.28^{B}$ & 16.50 & 6.00 & $13.29 \pm 0.13^{A}$ & 16.00 & 10.60 \\
\hline NBA & $12.29 \pm 0.15$ & 16.50 & 6.00 & $11.64 \pm 0.31^{B}$ & 16.50 & 6.00 & $12.67 \pm 0.14^{\mathrm{A}}$ & 15.44 & 10.00 \\
\hline NSB & $1.44 \pm 0.12$ & 7.50 & 0.00 & $0.88 \pm 0.24^{B}$ & 7.00 & 0.00 & $1.76 \pm 0.12^{A}$ & 7.50 & 0.00 \\
\hline LWB & $13.89 \pm 0.21$ & 22.30 & 7.80 & $13.42 \pm 0.37$ & 20.60 & 7.80 & $14.17 \pm 0.26$ & 22.30 & 10.77 \\
\hline
\end{tabular}

Later parities, parties from the third; SE, standard error; TNB, total number of piglets born; NBA, number of piglets born alive; NSB, number of still born piglets; LWB, litter weight at birth.

$A, B$ Means with different superscripts in the same row differ at $p<0.01$. 
Table 4. Association between single nucleotide polymorphisms (T3739C) and reproductive traits

\begin{tabular}{|c|c|c|c|c|c|}
\hline Parities & Genotype & TNB & NBA & NSB & LWB \\
\hline \multirow[t]{3}{*}{ Total parities } & AA & - & - & - & - \\
\hline & $A B$ & $11.85 \pm 0.44 B$ & $11.16 \pm 0.53 B$ & $1.48 \pm 0.46$ & $12.96 \pm 0.70$ \\
\hline & $\mathrm{BB}$ & $13.08 \pm 0.14 \mathrm{~A}$ & $12.44 \pm 0.15 \mathrm{~A}$ & $1.43 \pm 0.12$ & $14.02 \pm 0.22$ \\
\hline \multirow[t]{3}{*}{ First two parities } & $\mathrm{AA}$ & - & - & - & - \\
\hline & $A B$ & $10.43 \pm 0.56 B$ & $9.71 \pm 0.81 \mathrm{~B}$ & $1.14 \pm 0.99$ & $11.65 \pm 0.84 b$ \\
\hline & $\mathrm{BB}$ & $12.66 \pm 0.29 \mathrm{~A}$ & $11.98 \pm 0.31 \mathrm{~A}$ & $0.84 \pm 0.23$ & $13.73 \pm 0.39 a$ \\
\hline \multirow[t]{3}{*}{ Later parities } & AA & - & - & - & - \\
\hline & $A B$ & $13.09 \pm 0.17$ & $12.42 \pm 0.28$ & $1.77 \pm 0.22$ & $14.11 \pm 0.97$ \\
\hline & $\mathrm{BB}$ & $13.32 \pm 0.14$ & $12.70 \pm 0.15$ & $1.76 \pm 0.13$ & $14.18 \pm 0.27$ \\
\hline
\end{tabular}

TNB, total number of piglets born; NBA, number of piglets born alive; NSB, number of still born piglets; LWB, litter weight at birth; Later parities, parties from the third.

${ }_{A, B}$ Means with different superscripts in the same parities differ at $p<0.01$.

$a, b$ Means with different superscripts in the same parities differ at $p<0.05$.

for GPR54-C3878T (Table 5) and GPR54-T6789C (Table 6) loci, no significant difference was found in reproductive traits between all genotypes ( $p>0.05)$. The analysis also showed that allele B of C3878T locus had tendency to increase TNB, NBA, and LWB. These preliminary results showed an association between polymorphisms of GPR54 gene and reproduction in Jiaxing black sows and indicated that T3739C locus had the most significant influence on reproduction in sows of the first two parities.

\section{DISCUSSION}

A great deal of research has demonstrated that GPR54 gene displayed abundant polymorphisms in many mammals. De Roux et al [20] amplified exon5 of GPR54 gene from IHH patients and observed a deletion of 155 bp lying between intron4 and exon5. The sequences of the GPR54 gene from the CPP patients revealed the presence of six SNPs including 855061G/A, 855765A/G, 856737G/A, 859955C/A, 860460G/A and $860868 \mathrm{C} / \mathrm{G}$ as well [24]. Tang et al [25] reported that

Table 5. Association between single nucleotide polymorphisms (C3878T) and reproductive traits

\begin{tabular}{|c|c|c|c|c|c|}
\hline Parities & Genotype & TNB & NBA & NSB & LWB \\
\hline \multirow[t]{3}{*}{ Total parities } & $\mathrm{AA}$ & - & - & - & - \\
\hline & $A B$ & $12.19 \pm 0.49$ & $11.47 \pm 0.53$ & $1.39 \pm 0.43$ & $12.92 \pm 0.58$ \\
\hline & $\mathrm{BB}$ & $12.98 \pm 0.14$ & $12.34 \pm 0.15$ & $1.44 \pm 0.13$ & $13.95 \pm 0.22$ \\
\hline \multirow[t]{3}{*}{ First two parities } & $\mathrm{AA}$ & - & - & - & - \\
\hline & $A B$ & $11.67 \pm 1.01$ & $11.17 \pm 1.17$ & $0.33 \pm 0.33$ & $13.33 \pm 1.41$ \\
\hline & $\mathrm{BB}$ & $12.38 \pm 0.24$ & $11.67 \pm 0.32$ & $0.92 \pm 0.21$ & $13.42 \pm 0.39$ \\
\hline \multirow[t]{3}{*}{ Later parities } & $\mathrm{AA}$ & - & - & - & - \\
\hline & $A B$ & $12.58 \pm 0.47$ & $11.69 \pm 0.52$ & $2.19 \pm 0.31$ & $12.61 \pm 0.34$ \\
\hline & $B B$ & $13.33 \pm 0.13$ & $12.72 \pm 0.14$ & $1.74 \pm 0.12$ & $14.25 \pm 0.27$ \\
\hline
\end{tabular}

TNB, total number of piglets born; NBA, number of piglets born alive; NSB, number of still born piglets; LWB, litter weight at birth; Later parities, parties from the third.

Table 6. Association between single nucleotide polymorphism (T6789C) and reproductive traits

\begin{tabular}{|c|c|c|c|c|c|}
\hline Parities & Genotype & TNB & NBA & NSB & LWB \\
\hline \multirow[t]{3}{*}{ Total parities } & $\mathrm{AA}$ & - & - & - & - \\
\hline & $A B$ & $12.95 \pm 0.33$ & $12.19 \pm 0.35$ & $1.54 \pm 0.56$ & $13.88 \pm 0.48$ \\
\hline & $\mathrm{BB}$ & $12.94 \pm 0.14$ & $12.30 \pm 0.15$ & $1.43 \pm 0.12$ & $13.89 \pm 0.22$ \\
\hline \multirow[t]{3}{*}{ First two parities } & $\mathrm{AA}$ & - & - & - & - \\
\hline & $A B$ & $13.00 \pm 0.50$ & $12.75 \pm 0.25$ & $0.00 \pm 0.00$ & $15.23 \pm 0.58$ \\
\hline & $\mathrm{BB}$ & $12.30 \pm 0.29$ & $11.59 \pm 0.32$ & $0.92 \pm 0.25$ & $13.33 \pm 0.38$ \\
\hline \multirow[t]{3}{*}{ Later parities } & AA & - & - & - & - \\
\hline & $A B$ & $12.93 \pm 0.48$ & $11.92 \pm 0.47$ & $2.31 \pm 0.43$ & $13.20 \pm 0.26$ \\
\hline & $\mathrm{BB}$ & $13.31 \pm 0.13$ & $12.71 \pm 0.14$ & $1.73 \pm 0.12$ & $14.22 \pm 0.27$ \\
\hline
\end{tabular}

TNB, total number of piglets born; NBA, number of piglets born alive; NSB, number of still born piglets; LWB, litter weight at birth; Later parities, parties from the third. 
there were two mutations of GPR54 gene in Small Tail Han sheep, one nucleotide transition mutation (A125G) and one 5 bp deletion/insertion (TTCTT) mutation at the 163-167 loci in 5'-regulatory region of GPR54 gene. Chu et al [26] reported that two mutations (T2360C and A2411C) were only found in GPR54-Exon2 in prolific Hu sheep. A comparison of 45 amplified sequences of Indian indigenous goats resulted in identification of 2 novel SNPs, one was C1122T in exon1 and the other was T1830T in intron1 [27]. Feng et al [28] reported that five mutations, including C96T, T137C, G176A, G825A and C981T, were identified in exon1 and partial exon5 of GPR54 gene in Jining Grey goats. Cao et al [29] showed three mutation loci in exon 5 of GPR54 gene in five goat breeds, G4014A, G4136A, and C4152T. Li et al [18] reported that seven SNPs (T245C, C384T, T1411C, A1635G, G1766T, C2488A, and T3295C) were identified in the White Duroc $\times$ Erhualian intercross pigs and the mutation T245C showed quite different allele distribution in Chinese and Western breeds. The present study also detected three SNPs (T3739C, C3878T, and T6789C) in GPR54 gene in Jiaxing Black sows. The results all above together indicated a significant difference in the distribution of polymorphisms of GPR54 gene in different species, which may be related to the biological evolution of the gene.

According to correlation analysis, to some extent, we assumed that the polymorphisms of GPR54 gene were possibly related to reproductive function in Jiaxing Black sows and verified that T3739C could be a potential marker-assisted selection site that played an important role in reproduction trait. Apart from this present study, there have been many other studies indicated that GPR54 gene could have some effects on reproduction in animals. A series of literatures had identified the loss-of-function mutations of GPR54 gene could result in IHH in human and mice with impairment of pubertal maturation and reproductive function [14,19-21]. Teles et al [23] identified an autosomal dominant GPR54 mutation (Arg386Pro) that led to prolonged activation of intracellular signaling pathways in response to kisspeptins and appeared to be associated with CPP. Luan et al [24] also found a nonsynonymous mutation was statistically related to some cases of CPP. In addition to investigations on human beings, many studies have been reported on various animals, but the studies on pigs are still very limited. The report by Feng showed that Jining Grey goats with genotype $\mathrm{BB}$ and $\mathrm{AB}$ had 1.07 and 0.40 lambs more than those with genotype $\mathrm{AA}$, respectively, besides, genotype $\mathrm{DD}$ and $\mathrm{CD}$ had 1.80 and 0.55 lambs that were more than those with $\mathrm{CC}$, which suggested there was an association between alleles B, D and high litter size [28]. And as for the 4,152 locus, Jining Grey goat with genotype TT and CT had 1.02 and 0.84 kids more than those with genotype CC respectively [29]. Small Tail Han sheep ewes with genotype CC had 0.66 or 0.49 lambs more than those with genotype
DD or CD, respectively, which implied that allele $C$ at the 163 to 167 locus in GPR54 gene may be a potential marker for improving litter size in sheep [25]. Based on this present study, the results we observed from Jiaxing Black sows echoed the reports mentioned above that the gene could weigh somewhat on hormone metabolism and thereby affect reproductive traits.

However, there were some opposite findings that showed the polymorphisms of GPR54 gene were not associated with reproduction traits. Chu and his colleagues had found two mutations in exon 2 of ovine GPR54 gene, but the results were not able to justify the relation of GPR54 gene to litter size in sheep [26]. Li et al [18] also found seven SNPs in GPR54 gene, but no significant association of GPR54 haplotypes and haplotype pairs with age at puberty was observed in White Duroc and Erhualian pigs, implying that the mutations in GPR54 gene were not responsible for divergent age at puberty. Since the reproductive performance of animals is controlled by multi genes, in order to verify whether the GPR54 gene is the major gene or related gene which could affect prolificacy of sows, there is a need for further studies with more of breeds and animals to confirm the association of SNPs with reproductive traits.

\section{CONCLUSION}

The results of the present study provide, at first, the sequences of six exons as well as three SNP loci of GPR54 gene exons in Jiaxing Black sows. The present study preliminarily showed an association between the three SNP loci and reproductive traits which including TNB, NBA, NSB, and LWB in Jiaxing Black sows, thus indicating that the GPR54-T6789C locus may play an important role in reproductive function. But difference in reproductive traits for different genotypes requires additional data based on more animals to confirm the significant effect. At last, it should be efficient for researchers to make use of GPR54 gene exons polymorphisms for maker-assisted selection to improve reproductive performance of sows.

\section{CONFLICT OF INTEREST}

We certify that there is no conflict of interest with any financial organization regarding the material discussed in the manuscript. Li H-H, Xu M-S, Liu G-L are employees of Zhejiang Qinglian Food Company Limited.

\section{ACKNOWLEDGMENTS}

This study was supported by the Program of Breeding of New Species of Agricultural (Livestock and Poultry) in Zhejiang (2016C02054-3). 


\section{REFERENCES}

1. Lee DK, Nguyen T, O'Neill GP, et al. Discovery of a receptor related to the galanin receptors. FEBS Lett 1999;446:103-7. https://doi.org/10.1016/S0014-5793(99)00009-5

2. D'Anglemont DTX, Fagg LA, Dixon JP, et al. Hypogonadotropic hypogonadism in mice lacking a functional Kiss1 gene. Proc Natl Acad Sci USA 2007;104:10714-9. https://doi.org/10. 1073/pnas.0704114104

3. Dungan HM, Clifton DK, Steiner RA. Minireview: kisspeptin neurons as central processors in the regulation of gonadotropinreleasing hormone secretion. Endocrinology 2006;147:11548. https://doi.org/10.1210/en.2005-1282

4. Kotani M, Detheux M, Vandenbogaerde A, et al. The metastasis suppressor gene KiSS-1 encodes kisspeptins, the natural ligands of the orphan G protein-coupled receptor GPR54. J Biol Chem 2001;276:34631-6. https://doi.org/10.1074/jbc.M104847200

5. Muir AI, Chamberlain L, Elshourbagy NA, et al. AXOR12, a novel human $\mathrm{G}$ protein-coupled receptor, activated by the peptide KiSS-1. J Biol Chem 2001;276:28969-75. https://doi. org/10.1074/jbc.M102743200

6. Navarro VM, Castellano JM, Fernandez-Fernandez R, et al. Developmental and hormonally regulated messenger ribonucleic acid expression of KiSS-1 and its putative receptor, GPR54, in rat hypothalamus and potent luteinizing hormonereleasing activity of KiSS-1 peptide. Endocrinology 2004;145: 4565-74. https://doi.org/10.1210/en.2004-0413

7. An XP, Han P, Hou JX, et al. Molecular cloning and characterization of KISS1 promoter and effect of KISS1 gene mutations on litter size in the goat. Genet Mol Res 2013;12:4308-16. https:// doi.org/10.4238/2013.February.28.13

8. El-Tarabany MS, Zaglool AW, El-Tarabany AA, Awad A. Association analysis of polymorphism in KiSS1 gene with reproductive traits in goats. Anim Reprod Sci 2017;180:92-9. https:// doi.org/10.1016/j.anireprosci.2017.03.006

9. Maitra A, Sharma R, Ahlawat S, Tantia MS, Roy M, Prakash V. Association analysis of polymorphisms in caprine KiSS1 gene with reproductive traits. Anim Reprod Sci 2014;151:717. https://doi.org/10.1016/j.anireprosci.2014.09.013

10.Messager S, Chatzidaki EE, Ma D, et al. Kisspeptin directly stimulates gonadotropin-releasing hormone release via $\mathrm{G}$ protein-coupled receptor 54. Proc Natl Acad Sci USA 2005;102: 1761-6. https://doi.org/10.1073/pnas.0409330102

11. Shahab M, Mastronardi C, Seminara SB, Crowley WF, Ojeda SR, Plant TM. Increased hypothalamic GPR54 signaling: a potential mechanism for initiation of puberty in primates. Proc Natl Acad Sci USA 2005;102:2129-34. https://doi.org/10.1073/ pnas.0409822102

12.Dhillo WS, Chaudhri OB, Patterson M, et al. Kisspeptin-54 stimulates the hypothalamic-pituitary gonadal axis in human males. J Clin Endocrinol Metab 2005;90:6609-15. https://doi. org/10.1210/jc.2005-1468
13. Greives TJ, Mason AO, Scotti MA, et al. Environmental control of kisspeptin: implications for seasonal reproduction. Endocrinology 2007;148:1158-66. https://doi.org/10.1210/en.20061249

14. Funes S, Hedrick JA, Vassileva G, et al. The KiSS-1 receptor GPR54 is essential for the development of the murine reproductive system. Biochem Biophys Res Commun 2003;312: 1357-63. https://doi.org/10.1016/j.bbrc.2003.11.066

15. Herbison AE, de Tassigny X, Doran J, Colledge WH. Distribution and postnatal development of Gpr54 gene expression in mouse brain and gonadotropin-releasing hormone neurons. Endocrinology 2010;151:312-21. https://doi.org/10.1210/en. 2009-0552

16. Han SK, Gottsch ML, Lee KJ, et al. Activation of gonadotropinreleasing hormone neurons by kisspeptin as a neuroendocrine switch for the onset of puberty. J Neurosci 2005;25:11349-56. https://doi.org/10.1523/JNEUROSCI.3328-05.2005

17. Irwig MS, Fraley GS, Smith JT, et al. Kisspeptin activation of gonadotropin releasing hormone neurons and regulation of KiSS-1 mRNA in the male rat. Neuroendocrinology 2004;80: 264-72. https://doi.org/10.1159/000083140

18.Li S, Ren J, Yang G, Guo Y, Huang L. Characterization of the porcine Kisspeptins receptor gene and evaluation as candidate for timing of puberty in sows. J Anim Breed Genet 2008;125: 219-27.

19. Seminara SB, Messager S, Chatzidaki EE, et al. The GPR54 gene as a regulator of puberty. N Engl J Med 2003;349:161427. https://doi.org/10.1056/NEJMoa035322

20. de Roux N, Genin E, Carel JC, Matsuda F, Chaussain JL, Milgrom E. Hypogonadotropic hypogonadism due to loss of function of the KiSS1-derived peptide receptor GPR54. Proc Natl Acad Sci USA 2003;100:10972-6. https://doi.org/10.1073/pnas. 1834399100

21.Semple RK, Achermann JC, Ellery J, et al. Two novel missense mutations in $\mathrm{G}$ protein-coupled receptor 54 in a patient with hypogonadotropic hypogonadism. J Clin Endocr Metab 2005; 90:1849-55. https://doi.org/10.1210/jc.2004-1418

22. Tenenbaum-Rakover Y, Commenges-Ducos M, Iovane A, Aumas C, Admoni O, de Roux N. Neuroendocrine phenotype analysis in five patients with isolated hypogonadotropic hypogonadism due to a L102P inactivating mutation of GPR54. J Clin Endocrinol Metab 2007;92:1137-44. https://doi.org/10.1210/ jc.2006-2147

23. Teles MG, Bianco SD, Brito VN, et al. A GPR54-activating mutation in a patient with central precocious puberty. $\mathrm{N}$ Engl J Med 2008; 358:709-15. https://doi.org/10.1056/NEJMoa073443

24.Luan X, Yu H, Wei X, et al. GPR54 polymorphisms in Chinese girls with central precocious puberty. Neuroendocrinology 2007;86:77-83. https://doi.org/10.1159/000107511

25. Tang QQ, Chu MX, Cao GL, et al. Association between polymorphism of GPR54 gene and litter size in Small Tail Han sheep. Livest Sci 2012;143:97-103. https://doi.org/10.1016/ 
j.livsci.2011.09.005

26. Chu MX, Xiao CT, Feng T, et al. Polymorphisms of KiSS-1 and GPR54 genes and their relationships with litter size in sheep. Mol Biol Rep 2012;39:3291-7. https://doi.org/10.1007/s11033011-1097-3

27. Maitra A, Sharma R, Ahlawat S, Tantia MS. Novel genetic polymorphisms in caprine GPR54 gene associated with reproductive functions. Indian J Anim Sci 2014;84:1196-201.
28. Feng T, Zhao YZ, Chu MX, et al. Association between sexual precocity and alleles of KISS-1 and GPR54 genes in goats. Anim Biotechnol 2009;20:172-6. https://doi.org/10.1080/10495390 903004493

29. Cao GL, Chu MX, Fang L, Feng T, Di R, Li N. Analysis on DNA sequence of GPR54 gene and its association with litter size in goats. Mol Biol Rep 2011;38:3839-48. https://doi.org/10.1007/ s11033-010-0499-y 